\title{
Rapid
Communications in
Mass Spectrometry
}

\section{Gas-phase fragmentation of deprotonated tryptophan and its clusters $\left[\operatorname{Trp}_{n}-\mathrm{H}\right]^{-}$induced by different activation methods}

\begin{tabular}{|c|c|}
\hline Journal: & Rapid Communications in Mass Spectrometry \\
\hline Manuscript ID: & RCM-15-0129 \\
\hline Wiley - Manuscript type: & Research Article \\
\hline Date Submitted by the Author: & 27-Mar-2015 \\
\hline Complete List of Authors: & $\begin{array}{l}\text { Feketeova, Linda; Université de Lyon, Institut de Physique Nucléaire de } \\
\text { Lyon } \\
\text { Khairallah, George; The University of Melbourne, School of Chemistry } \\
\text { O'Hair, Richard; University of Melbourne, School of Chemistry } \\
\text { Nielsen, Steen ; University of Aarhus, }\end{array}$ \\
\hline Keywords: & $\begin{array}{l}\text { : singly deprotonated tryptophan clusters, tandem mass spectrometry, } \\
\text { collision-induced dissociation, electron-induced dissociation }\end{array}$ \\
\hline Abstract: & 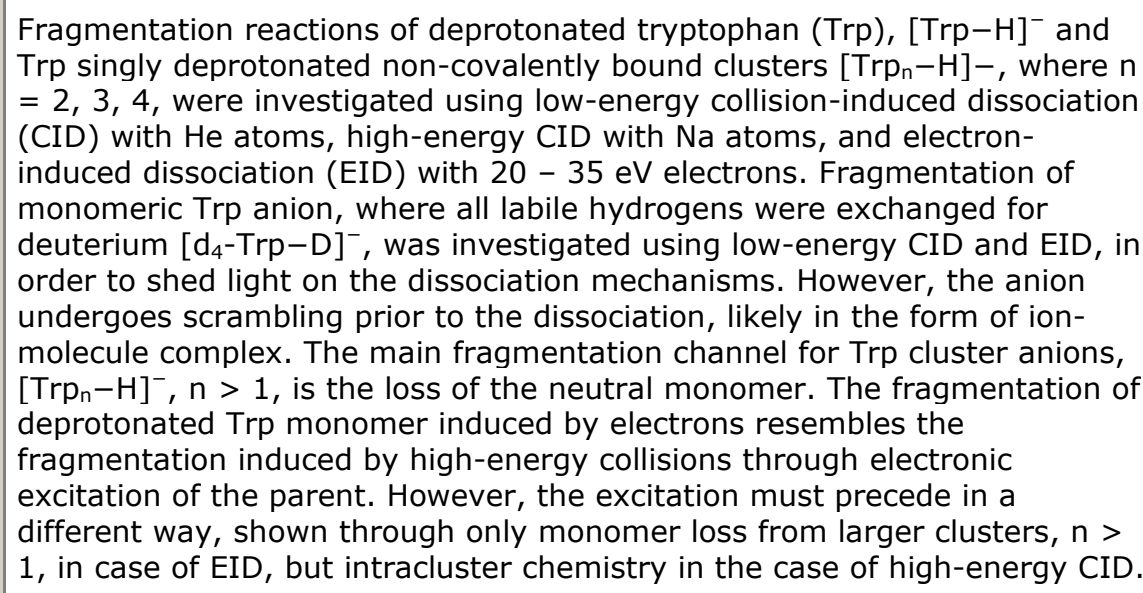 \\
\hline
\end{tabular}

\section{SCHOLARONE \\ Manuscripts}


Manuscript to be submitted to RCMS

\title{
Gas-phase fragmentation of deprotonated tryptophan and its clusters $\left[\operatorname{Trp}_{\mathrm{n}}-\mathrm{H}\right]^{-}$induced by different activation methods $^{\S}$
}

\author{
Linda Feketeová, ${ }^{a, b} *$ George N. Khairallah, ${ }^{a}$ Richard A. J. O’Hair ${ }^{a}$ \\ and Steen Brøndsted Nielsen ${ }^{c}$
}

(a) ARC Centre of Excellence for Free Radical Chemistry and Biotechnology, School of Chemistry and Bio21 Institute of Molecular Science and Biotechnology, The University of Melbourne, 30 Flemington Road, Parkville, Victoria 3010, Australia.

(b) Université de Lyon, 69003 Lyon, France; CNRS/IN2P3, UMR5822, Institut de Physique Nucléaire de Lyon, 69622 Villeurbanne, France.

(c) Department of Physics and Astronomy, Aarhus University, Ny Munkegade 120, Aarhus C, 8000 Denmark.

* Correspondence and PROOFS to: Dr. Linda Feketeová, E-mail: 1.feketeova@ipnl.in2p3.fr

$\S$ Dedicated to the memory of the late Professor Nico M. M. Nibbering. 


\begin{abstract}
Fragmentation reactions of deprotonated tryptophan (Trp), $[\operatorname{Trp}-\mathrm{H}]^{-}$and Trp singly deprotonated non-covalently bound clusters $\left[\operatorname{Trp}_{n}-\mathrm{H}\right]^{-}$, where $n=2,3,4$, were investigated using low-energy collision-induced dissociation (CID) with He atoms, high-energy CID with $\mathrm{Na}$ atoms, and electron-induced dissociation (EID) with $20-35 \mathrm{eV}$ electrons. Fragmentation of monomeric Trp anion, where all labile hydrogens were exchanged for deuterium $\left[d_{4^{-}}\right.$ Trp-D] $]^{-}$, was investigated using low-energy CID and EID, in order to shed light on the dissociation mechanisms. However, the anion undergoes scrambling prior to the dissociation, likely in the form of ion-molecule complex. The main fragmentation channel for Trp cluster anions, $\left[\operatorname{Trp}_{n}-\mathrm{H}\right]^{-}, n>1$, is the loss of the neutral monomer. The fragmentation of deprotonated Trp monomer induced by electrons resembles the fragmentation induced by high-energy collisions through electronic excitation of the parent. However, the excitation must precede in a different way, shown through only monomer loss from larger clusters, $n>$ 1, in case of EID, but intracluster chemistry in the case of high-energy CID.
\end{abstract}

Keywords: singly deprotonated tryptophan clusters; tandem mass spectrometry; collisioninduced dissociation; electron-induced dissociation;

Running Title: Fragmentation of $\left[\operatorname{Trp}_{n}-\mathrm{H}\right]^{-}$. 


\section{Introduction}

Tryptophan (Trp) is an essential amino acid, crucial for biological functioning of proteins and enzymes. ${ }^{[1]}$ It is a metabolic precursor of vitamin B5 (niacin) and of the hormone and neurotransmitter 5-hydroxytryptamine (serotonine). ${ }^{2 \text { and refs therein] }}$

Fragmentation of neutral $\operatorname{Trp}^{[3-6]}$ and protonated $\operatorname{Trp}^{[7-12]}$, i.e. $[\operatorname{Trp}+\mathrm{H}]^{+}$, has been subject of several studies using various fragmentation methods. Fragmentation of the Trp radical cation $\operatorname{Trp}^{\cdot+}$ showed different dissociation mechanism to even-electron protonated $\operatorname{Trp}$ $[\operatorname{Trp}+\mathrm{H}]^{+} .{ }^{[13]}$ Photodetachment of deprotonated Trp, i.e. $[\operatorname{Trp}-\mathrm{H}]^{-}$showed sensitivity of the Trp chromophore to the presence of remote negative charge. ${ }^{[14]}$ Fragmentation of deprotonated amino acid anions including Trp was investigated by Bowie and co-workers ${ }^{[15-}$ 17] and in a review ${ }^{[15]}$ Bowie outlined four major classes of fragmentation processes of organic negative ions including amino acids. These proceed through: (i) homolytic cleavage where loss of a radical forms stable radical anion; (ii) formation of anion complex; (iii) proton transfer toward deprotonated site thus forming a new anion; and (iv) rearrangement reactions. Positive- and negative-ion fragmentation spectra can be very different and thus provide useful complementary structural information for peptides. ${ }^{[18-21]}$ Additionally, the negative-ion fragmentation reactions of peptides are useful in identification of posttranslational modifications ${ }^{[18,22-24]}$ as well as more complete series of backbone fragments in peptide sequencing. ${ }^{[20,25]}$

Non-covalent amino acid clusters have been subject of intense research over past 20 years and covered diverse areas of interest, e.g. the use of fragmentation of proton-bound dimers to determine the gas-phase proton affinities ${ }^{[26]}$ or methylating abilities, ${ }^{[27]}$ peptide bond formation within amino acid clusters, ${ }^{[28]}$ formation and ionisation of neutral noncovalent amino acid complexes, ${ }^{[29-31]}$ or formation and fragmentation reactions of multiply 
charged clusters using various activation methods. ${ }^{[32-38]}$ Most of the research has focused on positive ions and only few report on anionic clusters of amino acids. ${ }^{[33,38]}$

Thus, in the present work we explore the fragmentation pattern of deprotonated Trp $[\mathrm{Trp}-\mathrm{H}]^{-}$after high-energy collisions with $\mathrm{Na}$ atoms, low-energy collisions with He and 25 $30 \mathrm{eV}$ free electrons. Mass spectra resulting from the experiments using collision-induced dissociation (CID) and electron-induced dissociation (EID) are presented. In addition, we have examined the unimolecular fragmentation chemistry of deprotonated Trp clusters $\left[\operatorname{Trp}_{n}-\mathrm{H}\right]^{-}$, where $n=2,3,4$, with these different activation methods. The use of collisions with sodium atoms offered an opportunity to look for the possibility of collisional electron transfer to the clusters to form doubly charged anions. ${ }^{[39]}$

\section{Experimental}

L-Tryptophan (purity $\geq 98 \%$ ) was used as received from Sigma-Aldrich (Milwaukee, USA). All experiments were carried out using a $1 \mathrm{mM}$ solution of tryptophan in $\mathrm{MeOH}$ on two different instruments: (i) a Finnigan- LTQ-FT (Thermo, Bremen, Germany) mass spectrometer equipped with electrospray ionization (ESI) source ${ }^{[40]}$ described in detail elsewhere, ${ }^{[41]}$ (ii) Separator Experiment described in detail previously. ${ }^{[42]}$ For labelling studies, Trp was dissolved in MeOD, which resulted in exchanging the labile $\mathrm{H}$ for $\mathrm{D}$, thus exchanging four hydrogens in the neutral Trp.

\section{(i) Low-energy CID and EID spectra on the LTQ-FT}

The tryptophan solution was introduced to the mass spectrometer at $5.0 \mu \mathrm{L} / \mathrm{min}$ via ESI in the negative mode. Typical ESI conditions used were: spray voltage, $2.2-4.0 \mathrm{kV}$, capillary temperature, $200-250{ }^{\circ} \mathrm{C}$, nitrogen sheath pressure, $5-25$ (arbitrary units). The capillary voltage and the tube lens offset were tuned to maximize the desired peak. The 
injection time was set using the automatic gain control function. The LTQ-FT mass spectrometer consists of: (i) linear ion trap (LTQ); (ii) ion transfer optics; and (iii) FT-ICR mass analyzer. For the tandem mass spectrometry experiments, the desired ions produced via ESI were mass selected, trapped in the LTQ and subjected to CID at a He bath gas pressure of ca. $5 \times 10^{-3}$ Torr at the room temperature. CID was carried out by mass selecting the desired ions with a $1.5-5 \mathrm{~m} / \mathrm{z}$ units window and subjecting them to the following typical conditions: normalized collision energy between 16 and 40, which determines the translational kinetic energy of the ions; activation $(\mathrm{Q}) 0.25-0.35$, which assigns the RF frequency used to fragment ions; and activation time of $30 \mathrm{~ms}$ that is the time set to excite the ions via CID. For high resolution mass analysis and EID, the ions were transferred via the ion optics transfer region $\left(\sim 2 \times 10^{-7}\right.$ Torr $)$ into an FT-ICR cell at a pressure below $1.5 \times 10^{-9}$ Torr. The FT-ICR cell is supplied with low-energy electrons produced by an indirectly heated emitter cathode located downstream of the FT-ICR cell. The energy of electrons is given by the potential difference between the emitter cathode with ECD offset of $-3.2 \mathrm{~V}$ and the grid positioned in front of the cathode, which is variable. Ions were bombarded with electrons of energies $20-35 \mathrm{eV}$ for $30-100 \mathrm{~ms}$. These conditions were carefully selected to maximise the fragment ion signal intensity and minimize secondary electron ion interaction in the cell. ${ }^{[9,37]}$

\section{(ii) High-energy CID on a sector instrument}

The tryptophan solution was introduced to the mass spectrometer via ESI in the negative mode. Ions were accelerated to $50 \mathrm{keV}, \mathrm{m} / \mathrm{z}$ selected by a bending magnet and passed through two collision chambers before the product ions were analysed by a hemispherical electrostatic analyser. ${ }^{[43,44]}$ A heated cell containing $\mathrm{Na}$ allowed for collisions 
with $\mathrm{Na}$ atoms in the first collision chamber. The second collision chamber was not used in the present experiments.

\section{Results and Discussion}

ESI of a $1 \mathrm{mM}$ solution of tryptophan (solvent: $\mathrm{MeOH}$ ) yields a series of cluster ions of the type $\left[\operatorname{Trp}_{n}-\mathrm{xH}\right]^{x-}$, where $x=1-4$, as observed in the recent study. ${ }^{[38]}$ However, the present work focuses on singly charged tryptophan cluster, i.e. $x=1,\left[\operatorname{Trp}_{n}-\mathrm{H}\right]^{-}, n=1,2,3$, 4.

\section{Fragmentation of $[\mathrm{Trp}-\mathrm{H}]^{-}$and $\left[\mathrm{d}_{4}-\mathrm{Trp}-\mathrm{D}\right]^{-}$}

Figure 1 shows low-energy CID in (a), high-energy CID in (b), and EID of [Trp-H] $]^{-}$ in (c). The mass selected precursor ion is always denoted by a star. Low-energy CID performed in the linear ion trap is slow heating process, resulting in fragmentation of ions through vibrational excitation. The low-energy CID of deprotonated tryptophan $[\mathrm{Trp}-\mathrm{H}]^{-}$ shows a number of fragment ions (Figure 1a). The dissociation pathways for $[\operatorname{Trp}-\mathrm{H}]^{-}$are summarised in Scheme 1, eqs. $1-7$, and the fragment ions resulting from the dissociation of $[\operatorname{Trp}-\mathrm{H}]^{-}$are shown in Scheme 2. The $[\operatorname{Trp}-\mathrm{H}]^{-}$is likely to be formed as the carboxylate anion, as the carboxylic acid group is the most acidic site ${ }^{[45]}$ and ESI generated $[\operatorname{Trp}-\mathrm{H}]^{-}$has been shown to exist as the carboxylate via the use of gas-phase IR spectroscopy. ${ }^{[46]}$ Indeed, the most abundant fragment ion at $m / z, 159$ arises via decarboxylation of [Trp-H] $]^{-}$(eq. 1). Decarboxylation of $\mathrm{RCH}_{2} \mathrm{CO}_{2}^{-}$has been reported and observed if the electron affinity of $\mathrm{R}^{\circ}$ is positive. ${ }^{[15,17]}$ Bowie suggested that ${ }^{[15]}$ the loss of $\mathrm{NH}_{3}$ proceeds through intramolecular $\mathrm{H}^{+}$ abstraction from $\mathrm{C}_{\beta} \mathrm{H}_{2}$ by carboxylate, and formation of an ion-molecule complex that leads to the formation of fragment ion at $m / z 186$ after dissociation (eq. 2). This fragment ion was also observed in the fast atom bombardment-collisional activation (FAB-CA) of [Trp-H $]^{-[16]}$ 
In order to shed light onto this process, Trp, where all labile hydrogens were exchanged for deuterium, was investigated by low-energy CID, see Figure 2a. One can see that $[\text { Trp-D }]^{-}$ undergoes complete intramolecular scrambling prior dissociation. This was observed earlier in the positive case $[\mathrm{Trp}+\mathrm{D}]^{+} \cdot{ }^{[7,47]}$ The presence of the fragment at $m / z 187$ due to the loss of $\mathrm{NHD}_{2}$ supports the suggestion that the $\mathrm{H}$ has been abstracted from $\mathrm{C}_{\beta}$. However, the observation of fragment at $m / z 186$, which is due to the loss of $\mathrm{ND}_{3}$, suggests abstraction from indole ring. Loss of $\mathrm{NH}_{2} \mathrm{D}$ forming fragment ion at $\mathrm{m} / \mathrm{z} 188$ suggests one of the $\mathrm{D}$ on the initial $\mathrm{ND}_{2}$ group underwent $\mathrm{H} / \mathrm{D}$ exchange in an ion-molecule complex prior to dissociation. Similarly, as suggested earlier by Bowie, ${ }^{[15]}$ the $\mathrm{CO}_{2}+\mathrm{NH}_{3}$ are lost through the same ionmolecule complex forming fragment at $\mathrm{m} / \mathrm{z} 142$ (eq. 3). The multistage mass spectrometry experiments have revealed that the $\mathrm{CO}_{2}$ is lost from the fragment ion at $\mathrm{m} / \mathrm{z} 186$ that has lost $\mathrm{NH}_{3}$ initially (data not shown). The ion abundances of fragment ions corresponding to loss of $\mathrm{NH}_{3}$ and $\mathrm{CO}_{2}$ in deuterated Trp (Figure 2a), i.e. fragment ions at $m / z 186$ (loss of $\mathrm{ND}_{3}$ ), $m / z$ 187 (loss of $\mathrm{NHD}_{2}$ ), and $m / z, 188$ (loss of $\mathrm{NH}_{2} \mathrm{D}$ ), resemble the relative ion abundances of $m / z$ 142 (loss of $\mathrm{CO}_{2}+\mathrm{ND}_{3}$ ), $m / z, 143$ (loss of $\mathrm{CO}_{2}+\mathrm{NHD}_{2}$ ), and $m / z 144$ (loss of $\mathrm{CO}_{2}+\mathrm{NH}_{2} \mathrm{D}$ ), respectively. The second most abundant fragment ion in the low-energy dissociation of $[\mathrm{Trp}-\mathrm{H}]^{-}$(Figure 1a) is the ion at $m / z, 116$, which is negatively charged indole ring (eq. 6). It is an unusual decomposition as noted by Bowie and co-workers, ${ }^{[16]}$ but it is present in all spectra in Figure 1 with relatively high abundance. Figure 2a shows $\mathrm{H}-\mathrm{D}$ scrambling for the corresponding peaks at $m / z 117-119$, where the most abundant is the indole ring with two deuteriums. Possibly the $\mathrm{H}$ has been abstracted from $\mathrm{C}_{\alpha}$ (eq. 6) forming ion-molecule complex that underwent $\mathrm{H}-\mathrm{D}$ exchange before dissociation. The fragment ion at $\mathrm{m} / \mathrm{z} 116$ showed to come also from further dissociation of the fragment ion at $\mathrm{m} / \mathrm{z} 159$ (Figure 1a), but in a low abundance. The fragment ion at $\mathrm{m} / \mathrm{z} 130$ can likely proceed through abstraction of $\mathrm{H}$ from $\mathrm{NH}_{2}$ group forming ion-molecule complex that can undergo further scrambling as 
shown in the deuterated case in Figure 2a, eq. $4 . \mathrm{MS}^{3}$ experiments shown that this fragment comes also from the fragment ion at $m / z$ 159. High resolution mass spectrometry confirmed that the fragment ion at $\mathrm{m} / \mathrm{z} 173$ is formed through loss of the amino methyl radical. - $\mathrm{CH}_{2} \mathrm{NH}_{2}$, which likely forms through an ion-molecule complex (eq. 7). Loss of such a radical was observed in the case of deprotonated glycine, ${ }^{[17]}$ but has not been observed via high-energy CID (Figure 1b), FAB-CA, ${ }^{[16]}$ or EID (Figure 1c). Minor loss of the side chain forms the fragment ion $\mathrm{H}_{2} \mathrm{~N}^{-} \mathrm{CHCO}_{2} \mathrm{H}$ at $\mathrm{m} / \mathrm{z}, 74$, through intramolecular abstraction of $\mathrm{H}^{+}$ from $\mathrm{NH}_{2}$ by the carboxylate to form an ion-molecule complex prior dissociation (eq. 5) that undergoes scrambling as shown in deuterated case (Figure 2a).

High-energy CID and EID leads to similar fragmentation spectra with relatively similar abundances of the formed fragment ions. There was no sign of the formation of dianions in collisional electron transfer from sodium. The most abundant fragment ion observed in the high-energy CID spectrum is the ion at $m / z, 158$ (Figure $1 \mathrm{~b}$ ), due to the loss of - $\mathrm{CO}_{2} \mathrm{H}$, with a smaller amount of a fragment ion forming at $m / z, 159$ due to the loss of $\mathrm{CO}_{2}$, which has been also observed in the low-energy CID. In the EID spectra, both ions are of similar abundance (Figure 1c). The EID of deuterated Trp anion (Figure 2b) resulted in the loss of $\bullet \mathrm{CO}_{2} \mathrm{H}$ with a slightly higher abundance than the loss of $\mathrm{CO}_{2}$. A minor loss of $\bullet \mathrm{CO}_{2} \mathrm{D}$ was also observed, suggesting the $\mathrm{H}$ could be lost from two different positions of the $\operatorname{Trp}$ anion. In the EID spectra of $[\mathrm{Trp}-\mathrm{H}]^{-}$a loss of $\mathrm{H} \bullet$ is observed. Bowie suggested the loss of $\mathrm{H} \bullet$ to come from $\mathrm{C}_{\alpha}$ carbon. ${ }^{[15]}$ This is supported by observation of loss of $\mathrm{H} \bullet$ in the EID of $\left[d_{4}-\operatorname{Trp}-\mathrm{D}\right]^{-}$(Figure $\left.2 \mathrm{~b}\right)$ ), but loss from $\mathrm{C}_{\beta}$ cannot be excluded. However, in the case of EID loss of $\mathrm{H} \cdot$ from $[\mathrm{Trp}+\mathrm{Na}]^{+}$, the loss from $\mathrm{C}_{\alpha}$ is preferred, supported by the DFT calculations. ${ }^{[47]}$ Fragment ion at $m / z 142$ due to the loss of $\mathrm{CO}_{2}$ and $\mathrm{NH}_{3}$ is observed in the high-energy CID and EID as in the case of low-energy CID. However, this fragment ion is missing in the EID spectra of deuterated Trp anion $\left[d_{4}-\operatorname{Trp}-\mathrm{D}\right]^{-}$(Figure 2b). As already 
mentioned, the formation of an indole ring negative fragment ion at $\mathrm{m} / \mathrm{z} 116$ is observed in all the activation methods. In the case of EID of the deuterated Trp anion (Figure 2b), the fragment anions of the indole ring are observed, possessing one $\mathrm{D}$ at $\mathrm{m} / \mathrm{z} 117$ and two $\mathrm{D}$ at $m / z$ 118. Thus, some scrambling must have taken place prior the dissociation. Loss of a side chain forming negatively charged backbone at $\mathrm{m} / \mathrm{z} 74$ (eq. 5) is observed with the highest abundance in the high-energy CID. High-energy CID and EID closely resembles the fragmentation spectra likely due to the similarity of the activation method leading to fragmentation through electronic excitation of $[\operatorname{Trp}-\mathrm{H}]^{-}$.

\section{[Insert Figure 1 and 2 here, please]}

\section{Fragmentation of $\left[\operatorname{Trp}_{2}-\mathrm{H}\right]^{-}$}

Dissociation spectra for deprotonated dimer $\left[\operatorname{Trp}_{2}-\mathrm{H}\right]^{-}$are shown in Figure 3 for lowenergy CID (a), high-energy CID (b) and EID (c). Vibrational excitation of the dimer leads to the neutral Trp loss and further loss of $\mathrm{CO}_{2}$ from the monomer $[\operatorname{Trp}-\mathrm{H}]^{-}$. No intracluster chemistry is observed as was in the case of some proton bound dimers. ${ }^{[27,41,48]}$ The loss of monomer is dominant channel in all three activation methods studied. The high-energy CID and EID show differences in the fragmentation of the dimer $\left[\operatorname{Trp}_{2}-\mathrm{H}\right]^{-}$. While high-energy CID leads to several fragments of $m / z$ above the monomer, EID shows preference for loss of a neutral Trp. This difference demonstrates the difference in the excitation induced by an electron and by high-energy collision with $\mathrm{Na}$ atoms for the deprotonated dimer $\left[\operatorname{Trp}_{2}-\mathrm{H}\right]^{-}$. It is noteworthy, that after high-energy collision, the constituents of the dimer are still noncovalently bound. High-energy CID leads to loss of 45 , likely due to the loss of $\bullet \mathrm{CO}_{2} \mathrm{H}$, as we observed in the case of the monomer. Fragment ion at $\mathrm{m} / \mathrm{z} 332$ corresponds to extra mass of 129 amu to the mass of the monomer, which is likely the side chain of the Trp, thus the 
backbone of one of the Trp within the dimer has been lost. If the side chain is lost and the backbone remains bounded to the neutral Trp, this gives rise to the fragment ion at $\mathrm{m} / \mathrm{z}, 276$ that is also observed, but with minor abundance. The fragment ion at $\mathrm{m} / \mathrm{z} 249$ is likely $\operatorname{Trp}$ bound to $\mathrm{HO}^{-} \mathrm{C}=\mathrm{O} \cdot{ }^{[15]}$ Different relative abundance of the fragments of $\mathrm{m} / \mathrm{z} 159,158$ and 116 in the EID of $\left[\operatorname{Trp}_{2}-\mathrm{H}\right]^{-}$, in comparison to the monomer $[\operatorname{Trp}-\mathrm{H}]^{-}$, suggest fragments at $\mathrm{m} / \mathrm{z}$ 159 and 116 come from vibrational excitation of the Trp constituent within the cluster, as it resembles the relative abundance of these fragments in CID of the monomer (Figure 1a). However, the appearance of the fragment ion at $\mathrm{m} / \mathrm{z} 158$ must come from electronic excitation of the cluster. These fragment ions arise from fragmentation of the dimer, likely due to the concomitant loss of the monomer, i.e. the neutral Trp. Again there was no sign of collisional electron transfer from $\mathrm{Na}$.

\section{[Insert Figure 3 here, please]}

\section{Fragmentation of $\left[\mathrm{Trp}_{3}-\mathrm{H}\right]^{-}$}

Figure 4 shows low-energy CID (a), high-energy CID (b) and EID (c) of the deprotonated $\operatorname{Trp}$ trimer $\left[\operatorname{Trp}_{3}-\mathrm{H}\right]^{-}$. Dissociation of the $\operatorname{Trp}$ within the cluster is observed only in the case of high-energy CID (Figure 4b). A dimer with an additional fragment corresponding to $45 \mathrm{amu}$ is observed at $\mathrm{m} / \mathrm{z}$ 452. The dominant fragmentation channel and the only one in the case of low-energy CID and EID is the loss of a neutral Trp (eq. 8).

\section{[Insert Figure 4 here, please]}

$$
\left[\operatorname{Trp}_{n}-\mathrm{H}\right]^{-} \quad \rightarrow \quad\left[\operatorname{Trp}_{n-m}-\mathrm{H}\right]^{-}+m \operatorname{Trp} \quad \text { (8) } \quad n>1
$$




\section{Fragmentation of $\left[\mathrm{Trp}_{4}-\mathrm{H}\right]^{-}$}

Figure 5 shows the low-energy CID (a) and high-energy CID (b) of the deprotonated Trp tetramer $\left[\operatorname{Trp}_{4}-\mathrm{H}\right]^{-}$. The observation of fragment ions at $m / z$ values above that of the mass selected precursor anion, highlights that the tetramer is contaminated by the doubly charged octamer $\left[\operatorname{Trp}_{8}-2 \mathrm{H}\right]^{2-}$. Doubly charged Trp clusters $\left[\operatorname{Trp}_{n}-2 \mathrm{H}\right]^{2-}$ have been investigated recently in a detailed study of $\left[\operatorname{Tr}_{9}-2 \mathrm{H}\right]^{2-}$ fragmentation induced by low-energy CID, ultraviolet photo-dissociation (UVPD) and EID. ${ }^{[38]}$ The doubly charged fragment cluster ion $\left[\operatorname{Trp}_{7}-2 \mathrm{H}\right]^{2-}$ observed through loss of a neutral $\operatorname{Trp}$ from $\left[\operatorname{Trp}_{8}-2 \mathrm{H}\right]^{2-}$, was the smallest doubly charged cluster observed in the previous study. ${ }^{[38]}$ Low-energy CID (Figure 5a) leads to competitive dissociation channels through loss of a neutral Trp from singly charged $\left[\operatorname{Trp}_{4}-\mathrm{H}\right]^{-}$(eq. 8) and a charge explosion reaction of the doubly charged contaminant cluster $\left[\operatorname{Trp}_{8}-2 \mathrm{H}\right]^{2-}$. In fact, recent high-resolution data ${ }^{[38]}$ revealed that the signal from the apparent $\left[\operatorname{Trp}_{4}-\mathrm{H}\right]^{-}$is largely due to the $\left[\operatorname{Trp}_{8}-2 \mathrm{H}\right]^{2-}$. High-energy CID (Figure 5b) shows additionally loss of an electron forming radical cluster ion $\left[\operatorname{Trp}_{8}-2 \mathrm{H}\right]^{\bullet-}$. Loss of an electron was observed in the UVPD of doubly charged Trp cluster $\left[\operatorname{Trp}_{9}-2 \mathrm{H}\right]^{2-} \cdot{ }^{[38]}$ Other fragments formed are similar to those observed in the low-energy CID due to the loss of neutral Trp molecules from $\left[\operatorname{Trp}_{4}-\mathrm{H}\right]^{-}$and $\left[\operatorname{Trp}_{8}-2 \mathrm{H}\right]^{2-}$ leading to fragment ions $\left[\operatorname{Trp}_{n}-\mathrm{H}\right]^{-}, n<4$, and $\left[\operatorname{Trp}_{7}-2 \mathrm{H}\right]^{2-}$, respectively. In the case of doubly charged parent ion $\left[\operatorname{Trp}_{8}-2 \mathrm{H}\right]^{2-}$, neutral loss competes with charge separation of the cluster leading to singly charged Trp fragment clusters $\left[\operatorname{Trp}_{n}-\mathrm{H}\right]^{-}+\left[\operatorname{Trp}_{m}-\mathrm{H}\right]^{-}$, where $n+m=8$.

\section{[Insert Figure 5 here, please]}




\section{Conclusions}

Gas-phase fragmentation of deprotonated tryptophan and its non-covalently bound singly deprotonated clusters $\left[\operatorname{Trp}_{n}-\mathrm{H}\right]^{-}$, where $n=1-4$, was investigated using low-energy CID with $\mathrm{He}$ atoms, high-energy CID with $\mathrm{Na}$ atoms, and free electrons of $20-35 \mathrm{eV}$ in the EID. For $n=1$, the main fragmentation channel in the low-energy CID is the loss of $\mathrm{CO}_{2}$, whereas in the high-energy CID and EID the loss of $\bullet \mathrm{CO}_{2} \mathrm{H}$ competes with the loss of $\mathrm{CO}_{2}$. The second most abundant fragment ion present in the spectra of all activation methods is the formation of the anion of indole ring $\mathrm{C}_{8} \mathrm{H}_{6} \mathrm{~N}^{-}$at $\mathrm{m} / z$ 116. Noteworthy, a radical cleavage was observed in the low-energy CID, where Trp parent anion has lost $\bullet \mathrm{CH}_{2} \mathrm{NH}_{2}$. For $n>1$, the main fragmentation channel is loss of neutral Trp. Only in the case of high-energy CID of clusters, minor fragments were observed, corresponding to the bond cleavages within the cluster. Thus, high-energy CID activates the parent cluster anion in a different way than EID. However, for $n=1$, the high-energy CID and EID showed similar abundance of formed fragment anions. No evidence for the formation of dianions in collisional electron transfer from sodium was found. On a final note, there has been interest in the formation of peptide bonds within cluster ions as a possible route to prebiotic peptides. ${ }^{[28 \mathrm{~b}]} \mathrm{We}$ find no evidence for this in the singly deprotonated clusters $\left[\operatorname{Trp}_{n}-\mathrm{H}\right]^{-}$.

\section{Acknowledgments:}

We thank the ARC for financial support through the ARC Centre of Excellence program. LF and GK thank the ARC for the awards of an APD and ARF Fellowships respectively. LF thanks the School of Chemistry for the award of Chemistry Small Grant. An ARC Lief grant and funding from the Victorian Institute for Chemical Sciences are acknowledged for the purchase of the LTQ-FT mass spectrometer. SBN acknowledges Lundbeckfonden for support. 


\section{References:}

[1] S. V. Jovanovic, M. G. Simic. Repair of tryptophan radicals by antioxidants. Life Chem. Rep. 1985, 3, 124.

[2] P. Gaikwad, K. I. Priyadarsini, B. S. M. Rao. Radiation chemistry research using PULAF. Radiat. Phys. Chem. 2008, 77, 1124.

[3] S. Sato, Z. He, M. Kaneda, M. Imai, H. Tsuchida Electron energy spectra from various amino acids bombarded by $2.0 \mathrm{MeV} \mathrm{He}+$ ions. Nucl. Instrum. Methods Phys. Res. B 2007, 256, 506.

[4] O. Plekan, V. Feyer, R. Richter, M. Coreno, K. C. Prince. Valence photoionization and photofragmentation of aromatic amino acids. Mol. Phys. 2008, 106, 1143.

[5] H. Abdoul-Carime, L. Sanche. Alteration of protein constituents induced by low-energy $(<35 \mathrm{eV})$ electrons: II. Dissociative electron attachment to amino acids containing cyclic groups. Radiat. Res. 2003, 160, 86.

[6] H. Abdoul-Carime, S. Gohlke, E. Illenberger. Fragmentation of tryptophan by lowenergy electrons. Chem. Phys. Lett. 2005, 402, 497.

[7] H. Lioe, R. A. J. O'Hair, G. Reid. Gas-phase reactions of protonated tryptophan. J. Am. Soc. Mass Spectrom. 2004, 15, 65.

[8] H. Lioe, R. A. J. O'Hair, G. Reid. A mass spectrometric and molecular orbital study of $\mathrm{H}_{2} \mathrm{O}$ loss from protonated tryptophan and oxidized tryptophan derivatives. Rapid. Commun. Mass Spectrom. 2004, 18, 978.

[9] H. Lioe, R. A. J. O'Hair. Comparison of collision-induced dissociation and electroninduced dissociation of singly protonated aromatic amino acids, cystine and related simple peptides using a hybrid linear ion trap-FT-ICR mass spectrometer. Anal. Bioanal. Chem. 2007, 389, 1429.

[10] H. El Aribi, G. Orlova, A. C. Hopkinson, K. W. M. Siu. Gas-phase fragmentation reactions of protonated aromatic amino acids: Concomitant and consecutive neutral eliminations and radical cation formations. J. Phys. Chem. A 2004, 108, 3844.

[11] H. Kang, C. Dedonder-Lardeux, C. Jouvet, S. Martrenchard, G. Grégoire, C. Desfrançois, J.-P. Schermann, M. Barat, J. A. Fayeton. Photo-induced dissociation of protonated tryptophan $\operatorname{TrpH}^{+}$: A direct dissociation channel in the excited states controls the hydrogen atom loss. Phys. Chem. Chem. Phys. 2004, 6, 2628.

112] V. Lepère, B. Lucas, M. Barat, J. A. Fayeton, V. J. Picard, C. Jouvet, P. Çarçabal, I. Nielsen, C. Dedonder-Lardeux, G. Grégoire, A. Fujii. Comprehensive characterization of the photodissociation pathways of protonated tryptophan. J. Chem. Phys. 2007, 127, 134313.

[13] C.K. Barlow, D. Moran, L. Radom, W.D. McFadyen, R.A.J. O’Hair. Metal-mediated formation of gas-phase amino acid radical cations. J. Phys. Chem. A 2006, 110, 8304.

[14] I. Compagnon, A.-R. Allouche, F. Bertorelle, R. Antoine, P. Dugourd. Photodetachment of tryptophan anion: an optical probe of remote electron. Phys. Chem. Chem. Phys. 2010, 12, 3399.

[15] J.H. Bowie. The fragmentations of even-electron organic negative ions. Mass Spectrom. Rev. 1990, 9, 349.

[16] R.J. Waugh, J. Bowie, R.N. Hayes. Collision induced dissociation of deprotonated peptides: Dipeptides containing phenylalanine, tyrosine, histidine and tryptophan. Int. J. Mass Spectrom. Ion Processes 1991, 107, 333.

[17] M. Eckersley, J.H. Bowie, R.N. Hayes. Collision-induced dissociation of deprotonated alpha-amino-acids - The occurrence of specific proton transfers preceding fragmentation. Int. J. Mass Spectrom. Ion Processes 1989, 93, 199. 
[18] K. Deguchi, H. Ito, Y. Takegawa, N. Shinji, H. Nakagawa, S.-I. Nishimura. Complementary structural information of positive- and negative-ion $\mathrm{MS}^{\mathrm{n}}$ spectra of glycopeptides with neutral and sialylated N-glycans. Rapid. Commun. Mass Spectrom. 2006, $20,741$.

[19] J. Laskin, Z. Yang. Energetics and dynamics of dissociation of deprotonated peptides: Fragmentation of angiotensin analogs. Int. J. Mass Spectrom. 2011, 308, 275.

[20] D. Pu, N. L. Clipston, C. J. Cassady. A comparison of positive and negative ion collision-induced dissociation for model heptapeptides with one basic residue. J. Mass Spectrom. 2010, 45, 297.

[21] H. J. Andreazza, T. Wang, C. J. Bagley, P. Hoffmann, J.H. Bowie. Negative ion fragmentations of deprotonated peptides. The unusual case of isoAsp: a joint experimental and theoretical study. Comparison with positive ion cleavages. Rapid. Commun. Mass Spectrom. 2009, 23, 1993.

[22] T. T. N. Tran, T. Wang, S. Hack, P. Hoffmann, J. H. Bowie. Can collision-induced negative-ion fragmentations of $[\mathrm{M}-\mathrm{H}]^{-}$anions be used to identify phosphorylation sites in peptides? Rapid. Commun. Mass Spectrom. 2011, 25, 3537.

[23] B. J. Williams, C. K. Barlow, K. L. Kmiec, W. K. Russell, D. H. Russell. Negative ion fragmentation of cysteic acid containing peptides: Cysteic acid as a fixed negative charge. J. Am. Soc. Mass Spectrom. 2011, 22, 1622.

[24] A. G. Harrison, A. B. Young. Fragmentation reactions of deprotonated peptides containing aspartic acid. Int. J. Mass Spectrom. 2006, 255-256, 111.

[25] A. Kalli, G. Grigorean, K. Håkansson. Electron induced dissociation of singly deprotonated peptides. J. Am. Soc. Mass Spectrom. 2011, 22, 2209.

[26] A. G. Harrison. The gas-phase basicities and proton affinities of amino acids and peptides. Mass Spectrom. Rev. 1997, 16, 201.

[27] E.J.H. Yoo, L. Feketeová, G.N. Khairallah, R.A.J. O'Hair. Intercluster reactions show that $\left(\mathrm{CH}_{3}\right)_{2} \mathrm{~S}^{+} \mathrm{CH}_{2} \mathrm{CO}_{2} \mathrm{H}$ is a better methyl cation donor than $\left(\mathrm{CH}_{3}\right)_{3} \mathrm{~N}^{+} \mathrm{CH}_{2} \mathrm{CO}_{2} \mathrm{H}$. Eur. J. Mass Spectrom. 2011, 17, 159.

[28] (a) H. Wincel, R. H. Fokkens, N. M. M. Nibbering. Peptide bond formation in gasphase ion/molecule reactions of amino acids: a novel proposal for the synthesis of prebiotic oligopeptides. Rapid Commun. Mass Spectrom. 2000, 14, 135; (b) A. Singh, S. Kaur, J. Kaur, P. Singh. Transformation of gas-phase amino acid clusters to dipeptides: a nice approach to demonstrate the formation of prebiotic peptides, Rapid Commun. Mass Spectrom. 2014, 28, 2019.

[29] M. Marksteiner, P. Haslinger, H. Ulbricht, M. Sclafani, H. Oberhofer, C. Dellago, M. Arndt. Gas-phase formation of large neutral alkaline-earth metal tryptophan complexes. J. Am. Soc. Mass. Spectrom. 2008, 19, 1021.

[30] F. Ferreira da Silva, S. Denifl, T. D. Märk, A. M. Ellis, P. Scheier. Electron attachment to amino acid clusters in helium nanodroplets: Glycine, alanine, and serine. J. Chem. Phys. 2010, 132, 214306.

[31] F. Ferreira da Silva, P. Bartl, S. Denifl, T. D. Märk, A. M. Ellis, P. Scheier. Formation of the magic L-serine octamer in helium nanodroplets. ChemPhysChem 2009, 11, 90.

[32] D. Zhang, L. Wu, K. J. Koch, R. G. Cooks. Arginine clusters generated by electrospray ionization and identified by tandem mass spectrometry. Eur. J. Mass Spectrom. 1999, 5,353 .

[33] Z. Takats, S. C. Nanita, R. G. Cooks, G. Schlosser, K. Vékey. Amino acid clusters formed by sonic spray ionization. Anal. Chem. 2003, 75, 1514.

[34] P. Nemes, G. Schlosser, K. Vékey. Amino acid cluster formation studied by electrospray ionization mass spectrometry. J. Mass Spectrom. 2005, 40, 43. 
[35] B. Concina, P. Hvelplund, A. B. Nielsen, S. B. Nielsen, J. Rangama, B. Liu, S. Tomita. Formation and stability of charged amino acid clusters and the role of chirality. J. Am. Soc. Mass Spectrom. 2006, 17, 275.

[36] L. Feketeová, R. A. J. O'Hair. Multiply protonated betaine clusters are stable in the gas phase. Chem. Commun. 2008, 4942.

[37] L. Feketeová, R. A. J. O'Hair. Electron-induced dissociation of doubly protonated betaine clusters: controlling fragmentation chemistry through electron energy. Rapid Commun. Mass Spectrom. 2009, 23, 3259.

[38] L. Feketeová, G. N. Khairallah, C. Brunet, J. Lemoine, R. Antoine, P. Dugourd, R. A. J. O'Hair. Fragmentation of the tryptophan cluster $\left[\operatorname{Trp}_{9}-2 \mathrm{H}\right]^{2-}$ induced by different activation methods. Rapid Commun. Mass Spectrom. 2010, 24, 3255.

[39] A. B. Nielsen, B. Liu, P. Hvelplund, S. Brøndsted Nielsen, S. Tomita. Coulomb explosion upon electron attachment to a four-coordinate monoanionic metal complex $J$. Am. Chem. Soc. 2003, 125, 9592.

[40] (a) R. Malek, W. Metelmann-Strupat, M. Zeller, H. Muenster. Electron capture dissociation on a hybrid linear ion trap/FTICR mass spectrometer. Am. Biotech. Lab. 2005, 23, 8; (b) S. Horning, R. Malek, A. Wieghaus, M. W. Senko, J. E. P. Syka. A hybrid two-dimensional quadrupole ion trap / Fourier transform ion cyclotron mass spectrometer: Accurate mass and high resolution at a chromatography timescale. Proceedings of the 51st ASMS conference mass spectrometry and allied topics 2003, Montreal.

[41] L. Feketeová, G. N. Khairallah, R. A. J. O’Hair. Intercluster chemistry of protonated and sodiated betaine dimers upon collision induced dissociation and electron induced dissociation. Eur. J. Mass Spectrom. 2008, 14, 107.

[42] (a) O. V. Boltalina, P. Hvelplund, T. J. D. Jørgensen, M. C. Larsen, M. O. Larsson, D. A. Sharoitchenko. Electron capture by fluorinated fullerene anions in collisions with Xe atoms. Phys. Rev. A 2000, 62, 7; (b) M. O. Larsson, P. Hvelplund, M. C. Larsen, H. Shen, H. Cederquist, H. T. Schmidt. Electron capture and energy loss in $\sim 100 \mathrm{keV}$ collisions of atomic and molecular ions on $\mathrm{C}_{60}$. Int. J. Mass Spectrom. 1998, 177, 51.

[43] O. V. Boltalina, P. Hvelplund, T. J. D. Jørgensen, M. C. Larsen, M.O. Larsson, D. A. Sharoitchenko, Electron capture by fluorinated fullerene anions in collisions with Xe atoms. Phys. ReV. A 2000, 62, 023202.

[44] M. O. Larsson, P. Hvelplund, M. C. Larsen, H. Shen, H. Cederquist, H. T. Schmidt. Electron capture and energy loss in similar to $100 \mathrm{keV}$ collisions of atomic and molecular ions on C60. Int. J. Mass Spectrom. Ion Processes 1998, 177, 51.

[45] (a) R. A. J. O'Hair, J. H. Bowie, S. Gronert. Gas phase acidities of the alpha-aminoacids. Int. J. Mass Spectrom. Ion Proc. 1992, 117, 23; (b) C. M. Jones, M. Bernier, E. Carson, K. E. Colyer, R. Metz, A. Pawlow, E. D. Wischow, I. Webb, E. J. Andriole, J. C. Poutsma. Gas-phase acidities of the 20 protein amino acids. Int. J. Mass Spectrom. 2007, 267, 54; (c) V. Riffet, S. Bourcier, G. Bouchoux. Gas-phase basicity and acidity of tryptophan. Int. J. Mass Spectrom. 2012, 316-318, 47; (d) M. L. Stover, V. E. Jackson, M. H. Matus, M. A. Adams, C. J. Cassady, D. A. Dixon. Fundamental thermochemical properties of amino acids: Gas-phase and aqueous acidities and gasphase heats of formation. J. Phys. Chem. B 2012, 116, 2905; (e) K. M. Uddin, P. L. Warburton, R. A. Poirier. Comparisons of computational and experimental thermochemical properties of $\alpha$-amino acids. J. Phys. Chem. B 2012, 116, 3220.

[46] J. Oomens, J. D. Steill, B. Redlich. Gas-phase IR spectroscopy of deprotonated amino acids. J. Am. Chem. Soc. 2009 , 131, 4310.

[47] L. Feketeová, M.W. Wong, R.A.J. O'Hair. The role of metal cation in electron-induced dissociation of tryptophan. Eur. Phys. J. D 2010, 60, 11. 
[48] J. A. Wyer, L. Feketeová, S. B. Nielsen, R. A. J. O'Hair. Gas phase fragmentation of protonated betaine and its clusters. Phys. Chem. Chem. Phys. 2009, 11, 8752. 


\section{Scheme 1}

Dissociation pathways for $[\operatorname{Trp}-\mathrm{H}]^{-}$. "Ar" stands for aromatic side chain of the Trp.

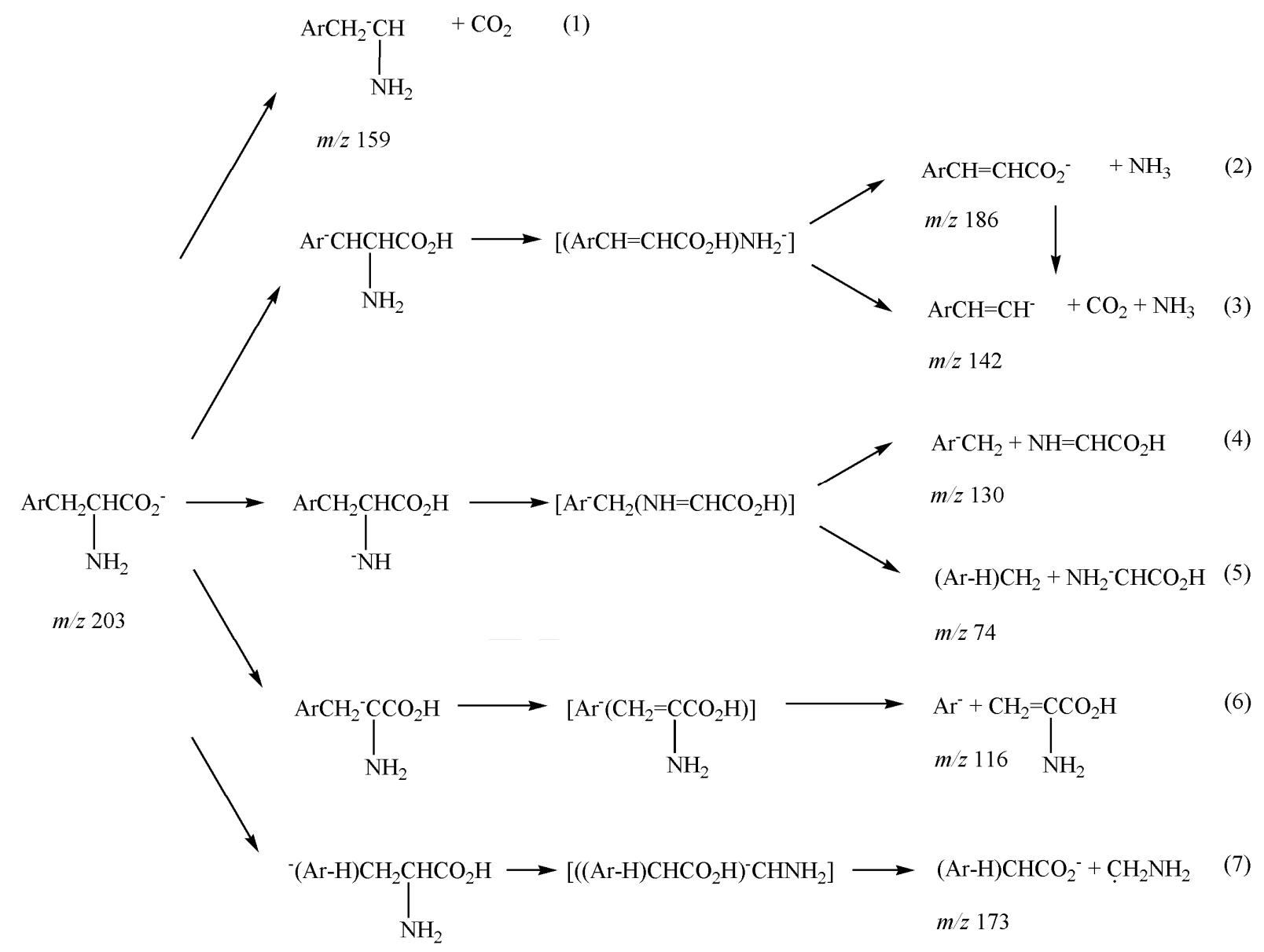




\section{Scheme 2}

Fragment ions resulting from the dissociation of $[\operatorname{Trp}-\mathrm{H}]^{-}$.

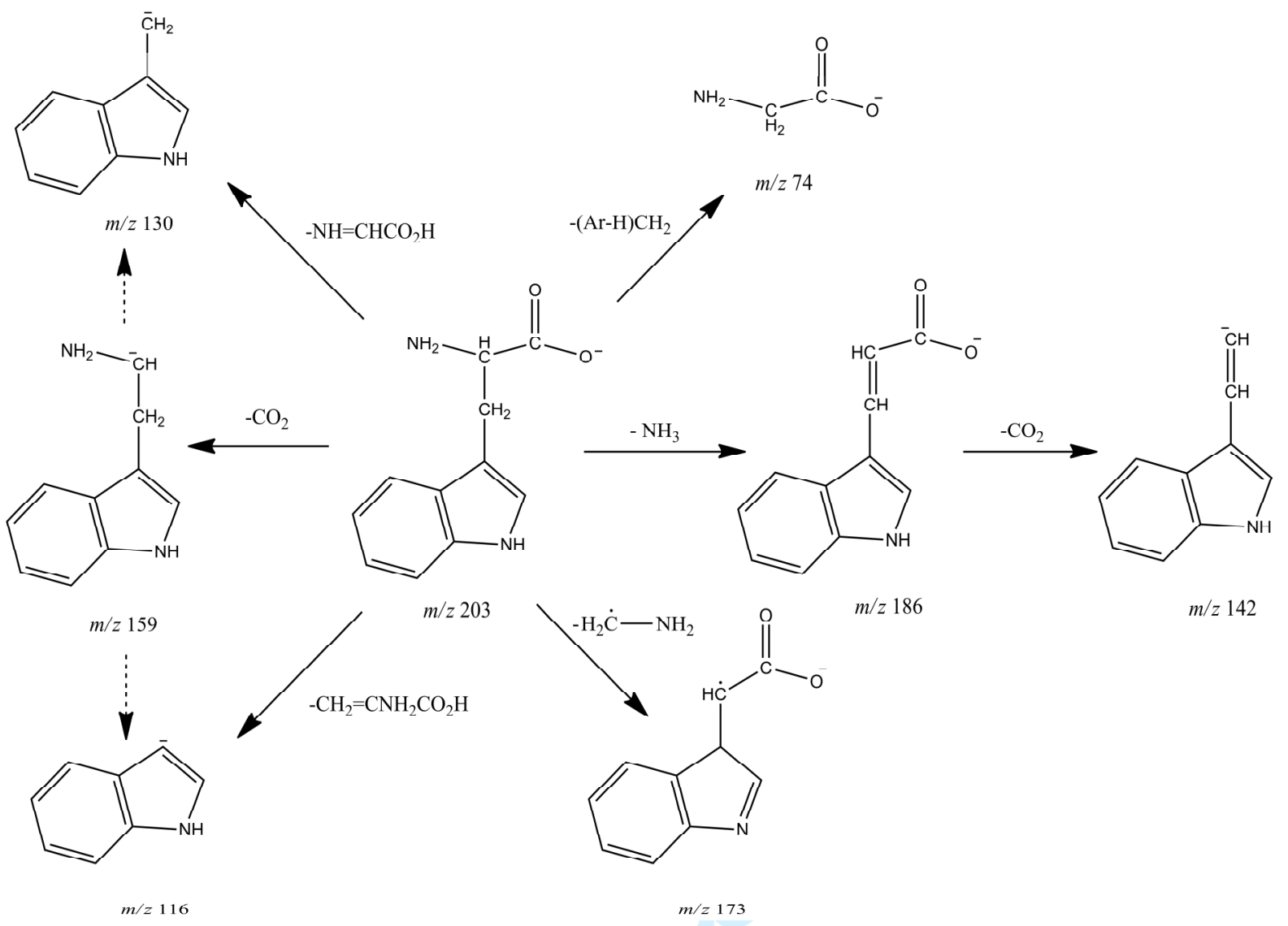




\section{Figure captions}

Figure 1: Fragmentation spectra of the monomer [Trp-H] ${ }^{-} m / z$ 203: (a) low-energy CID in the linear ion trap (collision energy 34, activation time $30 \mathrm{~ms}$ ); (b) high-energy CID with Na; (c) EID in the FT-ICR (electron energy $31.8 \mathrm{eV}$, activation time $30 \mathrm{~ms}$ ).

Figure 2: Fragmentation spectrum of the deuterated monomer $\left[d_{4}-\operatorname{Trp}-\mathrm{D}\right]^{-} m / z$ 206: (a) at low-energy CID in the linear ion trap (collision energy 29, activation time $30 \mathrm{~ms}$ ). Only the most abundant peaks are labelled for clarity. Adjacent peaks of $\Delta m / z= \pm 1$ correspond to same fragment with one more or less deuterium exchanged. All the peaks were confirmed using high-resolution FT-ICR mass analysis. (b) EID in the FT-ICR (electron energy $21.8 \mathrm{eV}$, activation time $70 \mathrm{~ms}$.

Figure 3: Fragmentation spectra of the dimer $\left[\operatorname{Trp}_{2}-\mathrm{H}\right]^{-} m / z$ 407: (a) low-energy CID in the linear ion trap (collision energy 17, activation time $30 \mathrm{~ms}$ ); (b) high-energy CID with Na; (c) EID in the FT-ICR (electron energy $27.4 \mathrm{eV}$, activation time $100 \mathrm{~ms}$ ).

Figure 4: Fragmentation spectra of the trimer $\left[\operatorname{Trp}_{3}-\mathrm{H}\right]^{-} m / z$ 611: (a) low-energy CID in the linear ion trap (collision energy 19, activation time $30 \mathrm{~ms}$ ); (b) high-energy CID with Na; (c) EID in the FT-ICR (electron energy $27.4 \mathrm{eV}$, activation time $40 \mathrm{~ms}$ ).

Figure 5: Fragmentation spectra of the tetramer $\left[\operatorname{Trp}_{4}-\mathrm{H}\right]^{-} \mathrm{m} / z$ 815: (a) low-energy CID in the linear ion trap (collision energy 20, activation time $30 \mathrm{~ms}$ ); (b) high-energy CID with Na. 
Figure 1:

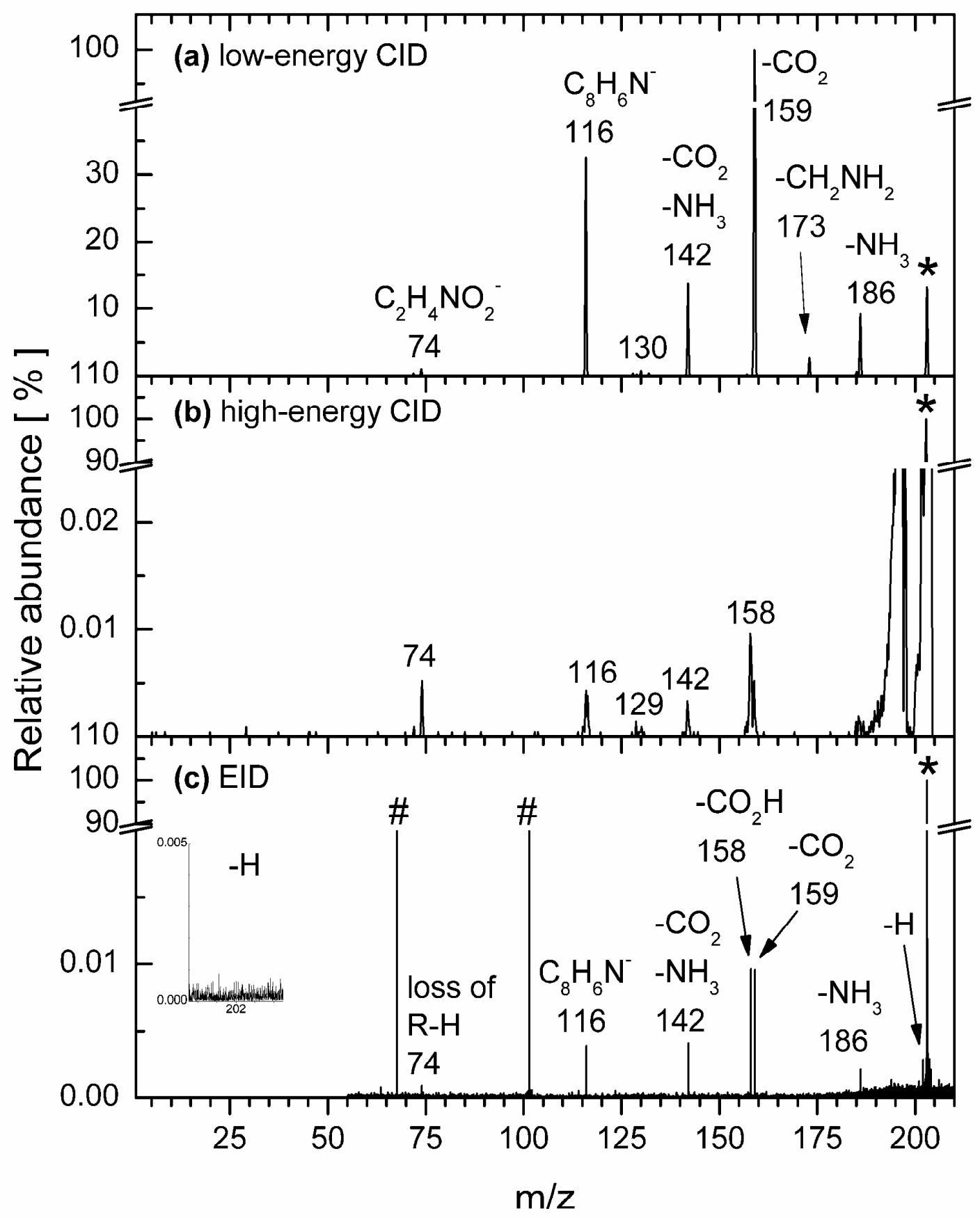


Figure 2:

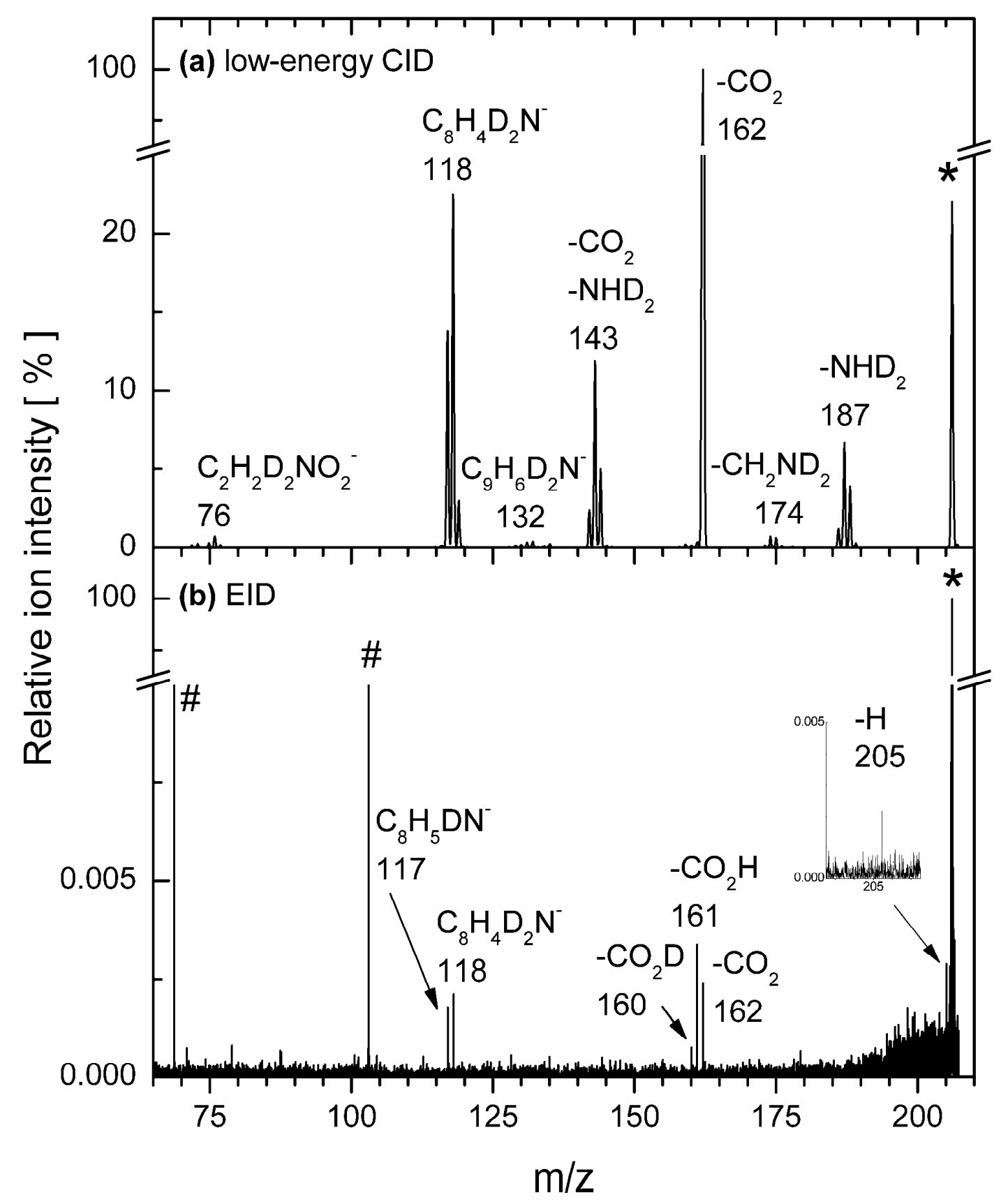


Figure 3:

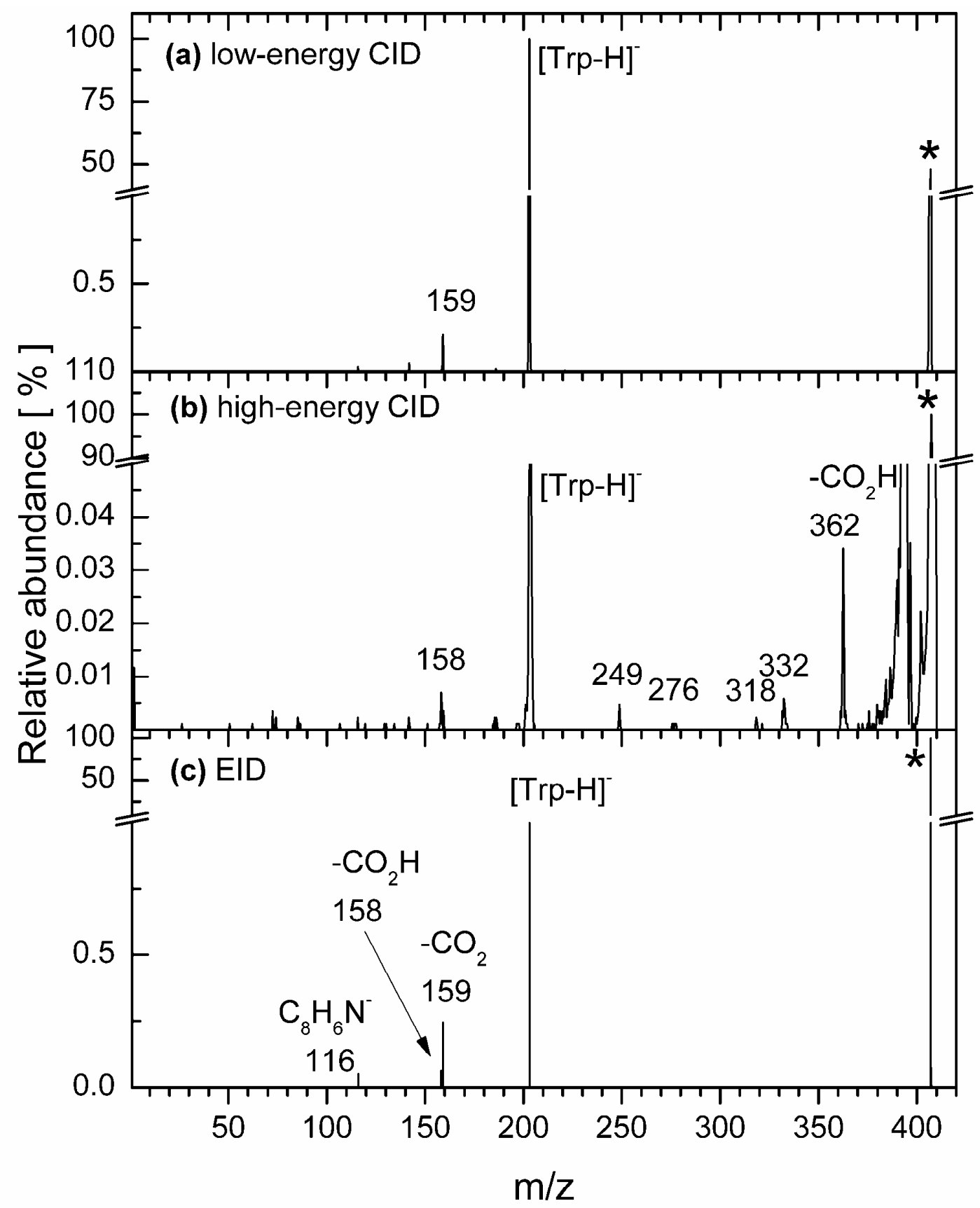


Figure 4:

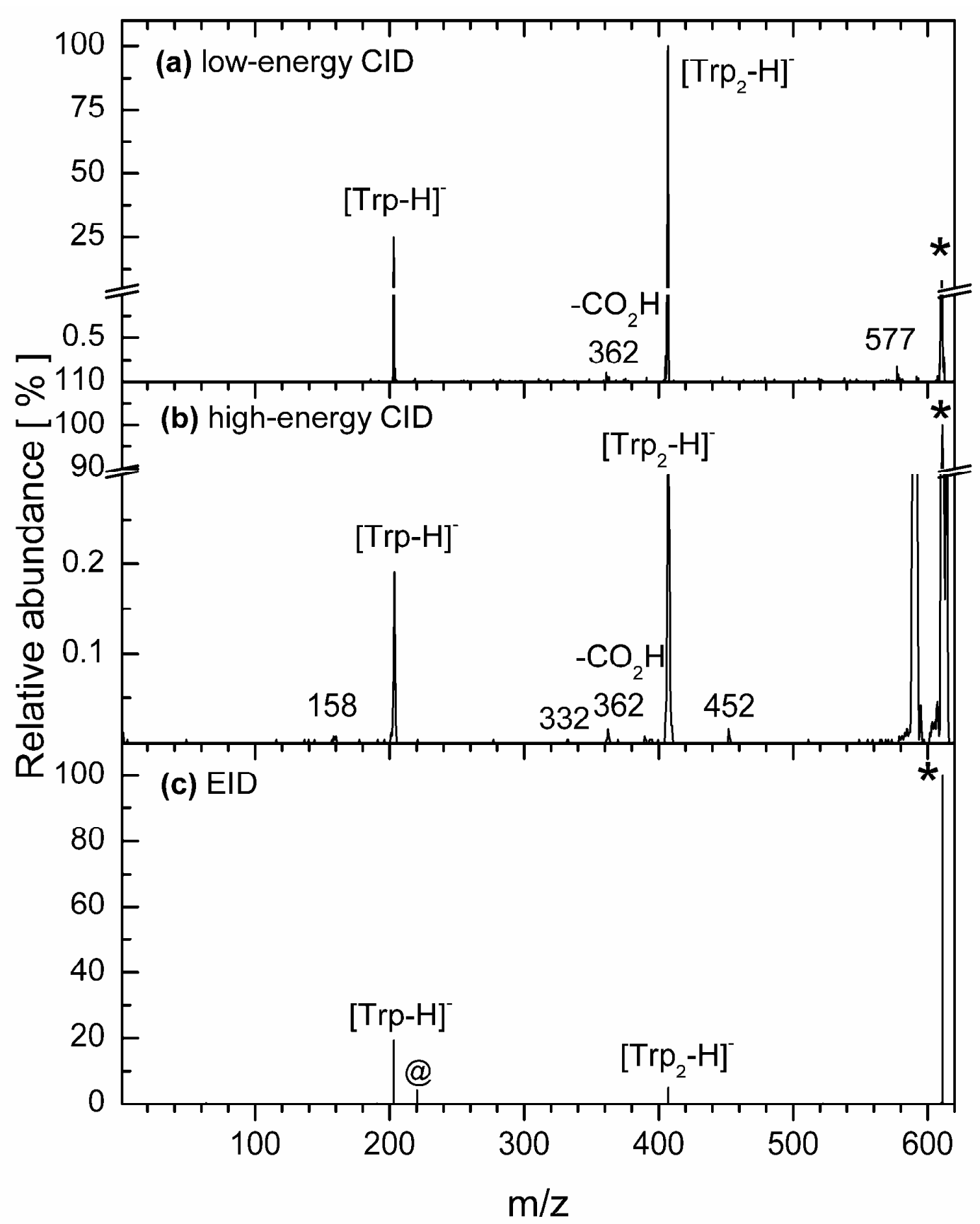


Figure 5:

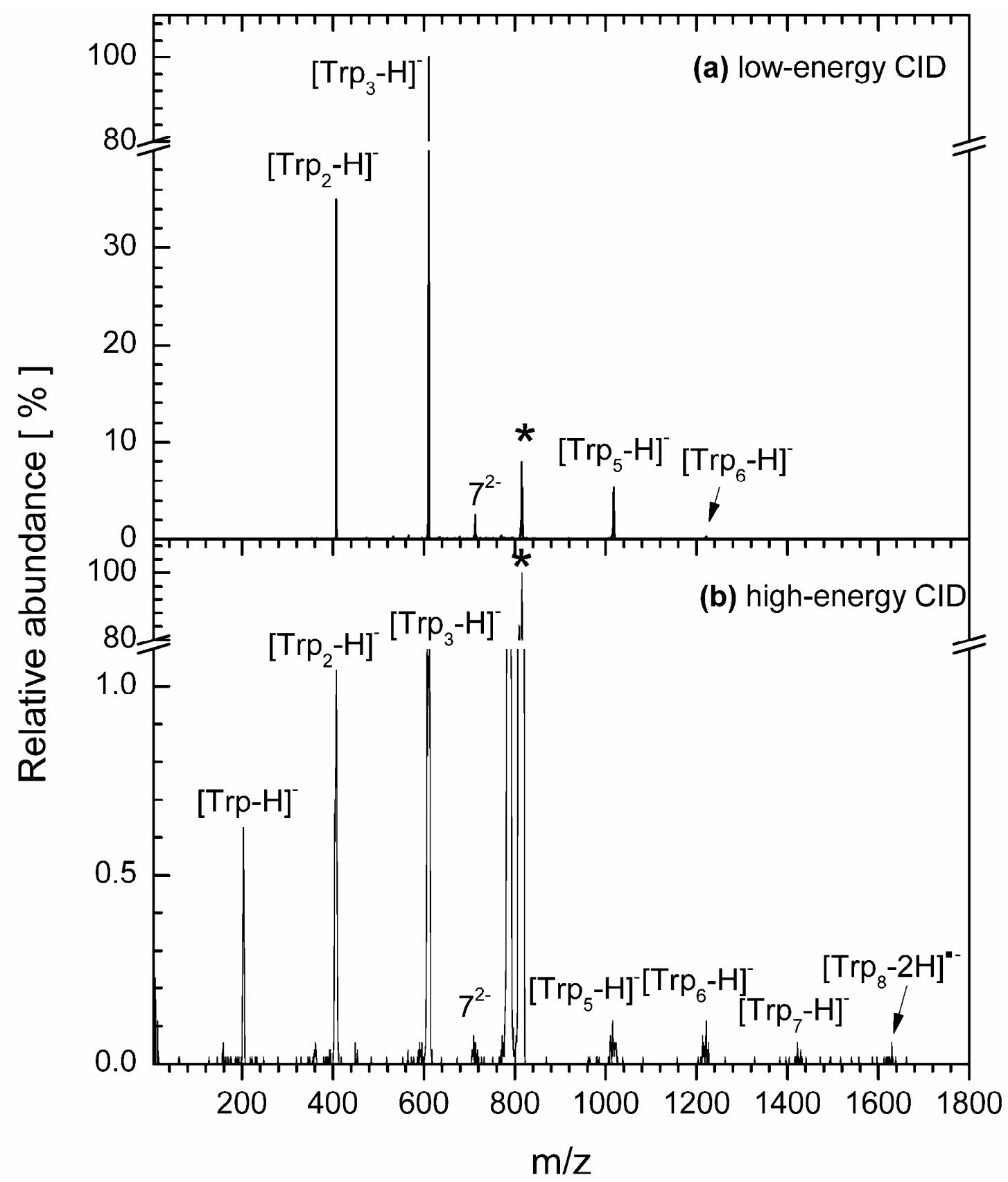




\section{University Library}

\section{- M M N E R VA A gateway to Melbourne's research publications}

Minerva Access is the Institutional Repository of The University of Melbourne

Author/s:

Feketeova, L;Khairallah, GN;O'Hair, RAJ;Nielsen, SB

Title:

Gas-phase fragmentation of deprotonated tryptophan and its clusters [Trp(n)-H](-) induced by different activation methods

Date:

2015-08-15

Citation:

Feketeova, L., Khairallah, G. N., O'Hair, R. A. J. \& Nielsen, S. B. (2015). Gas-phase fragmentation of deprotonated tryptophan and its clusters [Trp(n)-H](-) induced by different activation methods. RAPID COMMUNICATIONS IN MASS SPECTROMETRY, 29 (15), pp.1395-1402. https://doi.org/10.1002/rcm.7233.

Persistent Link:

http://hdl.handle.net/11343/57492 